The Catholic University of America, Columbus School of Law

CUA Law Scholarship Repository

\title{
Genetic Enhancement Technologies and The New Society
}

George P. Smith II

The Catholic University of America, Columbus School of Law

Follow this and additional works at: https://scholarship.law.edu/scholar

Part of the Genetic Processes Commons

\section{Recommended Citation}

George P. Smith, II, Genetic Enhancement Technologies and The New Society, 84 MED. L. INT'L. 85 (2000).

This Article is brought to you for free and open access by the Faculty Scholarship at CUA Law Scholarship Repository. It has been accepted for inclusion in Scholarly Articles and Other Contributions by an authorized administrator of CUA Law Scholarship Repository. For more information, please contact edinger@law.edu. 
Medical Law International, 2000, Vol. 4, pp. 85-95

$0968-5332 / 00 \$ 10$

(C) 2000 A B Academic Publishers-Printed in Great Britain

\title{
GENETIC ENHANCEMENT TECHNOLOGIES AND THE NEW SOCIETY
}

\author{
GEORGE P. SMITH, II
}

Catholic University Law School, Washington, D.C. 20064, USA

\begin{abstract}
So long as procreation continues to remain a central driving force in a marital relationship, and the family the very core of progressive society, efforts will be undertaken to expand the period of fecundity and combat infertility. Genetic planning and eugenic programming are more rational and humane alternatives to population regulation than death by famine and war.

Genetic enhancement technologies and the scientific research undertaken to advance them should be viewed as not only aiding (or, sometimes resolving) the tragedy of infertility in family planning, but as a tool for enhancing the health of a Nation's citizens by engineering man's genetic weaknesses out of the line of inheritance. Put simply, healthier and genetically sound individuals have a much better opportunity for pursuing and achieving the "good life" and making a significant contribution to society's greater well being.
\end{abstract}

\section{INTRODUCTION}

Both the sperm counts of men, world-wide, appear to be dropping precipitously together with the quality of the sperm itself. What this means essentially is that the percentage of healthy, vigorous cells versus malformed, sluggish ones, is in major decline. The net result of this is that there has been a significant drop in male fertility (Lemonick, 1996; Joffee, 1996).

While stress, smoking, drug use, sexually transmitted diseases and the very decision by men to have children later in life when sperm counts diminish are all causes - it is thought - contributing to this national problem, there are strong suggestions that environmental estrogens (e.g., DDT, some forms of dioxins and PCBs) are also contributing to this reproductive problem (Lemonick, 1996). When it is considered, additionally, that over 4,000 inherited disorders have been identified (Furrow et al., 1991), there is every reason for concern to be given to eugenics and the quality of the national gene pool.

Considerable research into techniques for perfecting genetic engineering has been undertaken in an attempt to develop new treatment for individuals with inherited diseases. Under the rubric of the "New 
Biology," scientists are investigating and developing many interventions, including gene deletion surgery, splicing and transplantation, cloning, in vitro or test tube fertilization, embryo implantation, parthenogenis, amniocentesis, and experimentation with the scope and application of DNA. Genetic engineering uses some of these procedures to reorganize human genes to produce varied, particular characteristics (Rifkin, 1998).

To combat genetic disease, genetic engineering may, and frequently does, rely upon eugenics, the science that deals with improving heredity. Indeed, genetic enhancement technologies are, by their very nature, tools of engineers. Thus, a positive eugenics program seeks to develop superior qualities in man through the propagation of his superior genes, and the positive eugenists seeks to produce a "new breed" with keener and more creative intelligence. Conversely, a negative eugenics program attempts only to eliminate genetic weaknesses. When seen in application, positive eugenics programs encourage the genetically fit and "proper" to reproduce, while negative eugenics programs discourage those less fit and those with inheritable diseases from procreating. Abortion is one way of implementing a program of negative eugenics after earlier attempts to regulate have failed (Smith, 1989).

\section{THE NEW EUGENICS}

With the introduction of contemporary molecular biology into prenatal testing, society is being led - inescapably - into eugenics - albeit from a far differently focused level than in Nazi Germany during World War II. There are, to be sure, fears that this new laissez-faire eugenics will seek to transform the population in a particular direction - thus not advancing an inherent goal of eugenics to avoid suffering, but rather reflecting and advancing a particular set of social values. Today, parents may - through genetic screening on in utero testing - learn whether a prospective offspring will be born with, for example, neurofibromatosis or Hurler syndrome; and knowing this may take what action is deemed appropriate (Kitcher, 1996).

Utopian Eugenics seeks to uncover those considerations which should or may guide reproductive choices. Thus, for example, a high priority of this science is assessing the array of fetal characteristics which would lead responsible people to terminate a pregnancy. Utopian Eugenics seeks not to coerce parents, but rather to educate them and furthermore - seeks no societally imposed restrictions on reproductive choice. Accordingly, this science seeks to foster an understanding - by and through education - that when the fetus suffers from serious irreversible genetic disease abortion is appropriate (Kitcher, 1996). When it is determined that a fetus has no chance of self-determination, as with early-onset neurodegenerative disorders, or in cases where a low quality 
of life combines with a large impact on the lives of others (as when it tests positive for degenerative muscular disease and the parents-to-be are already struggling to make a decent living for themselves and other existing children), Utopian eugenicists would suggest a clear case for abortion exists. And, they in turn, would stress - by way of justifying their position - that since disease is a matter of objective for the prevention of it has nothing to do with imposing social values (Kitcher, 1996).

However one chooses to view the field of molecular biology - as an out-an-out attack on the right to life movement - or an exciting aspect of modern science, one fact is indisputable: namely, the field, itself, presents and "unimaginable ocean of truth" with which contemporary society must deal. It cannot be sealed-off and closeted as a forbidden zone of simply theoretical knowledge (Heyd, 1992).

\section{HUMAN RIGHTS AND THE NEW BIOTECHNOLOGY}

Until quite recently, the pervasive attitude among sophisticated observers has been one of support for scientific inquiry and discovery. It is believed that this progressive action is not only of overwhelming benefit to society, but an essential attribute of human achievement and progress in the brave new world (Kirby, 1986). Subsequent agonizing reflections on the horrors of the World Wars and the all too frequent limited conflicts since 1945, together sometimes with overly emotional concerns regarding the full potential for nuclear, bacteriological and chemical warfare and its very real potential for annihilating mankind, have witnessed a new and increasingly pessimistic temperament concerning scientific advancement. Indeed, it has been recognized that "not all science is good for humanity" (Kirby, 1986).

The importance of human rights and its need to be recognized in the era of the "New Biology" was underscored by initial efforts at the United Nations in the 1970s. But before that activity, the 1948 Universal Declaration of Human Rights guarantees of "human dignity" written in Articles 1, 5, 6 and 29(1) established eloquent reminders of the need for the advances of biotechnology and genetic engineering to be tied to a basic understanding of, and respect for, fundamental human rights (Kirby, 1986).

A new human rights debate needs to emerge among not only the legal community, but also among the scientists and technocrats; a debate that would reconsider the extent to which both the traditional and redefined rights of humanity are challenged or complemented by the plethora of medical, legal, scientific and technological considerations of today's brave new world. Justice Michael D. Kirby of the High Court of Australia summarized succinctly the issue: "If lawyers are to continue to play a relevant part in the human rights debate of the future, they must 
become more aware of scientific and technological advances. Otherwise, they will increasingly lack understanding of the questions to be asked, let alone the answers to be given" (Kirby, 1986).

Law needs to direct an agenda for social change and changing social needs rather than simply responding or reacting to change. Indeed, the late former Chief Justice of the United States, Warren E. Burger, observed, "The law does not search out as do science and medicine; it reacts to social needs and demands" (Burger, 1982). Law, science and medicine must become partners. They must assure society today and tomorrow, that all citizens have an equal opportunity to achieve their maximum potential within the economic marketplace, have their physical suffering minimized and spiritual tranquility maintained.

\section{OPPORTUNITIES FOR THE NEW BIOLOGY IN AMERICA}

Improvement of man's genetic endowment by striving for positive propagation of those with a superior genetic make-up or, conversely, delimitation of those with negative genetic inheritance, has always been a primary concern in the field of genetics. If the quality of life in some way may be improved or advanced by use of law as it relates to genetics, then such must be undertaken. No longer does the Dostoevskian quest to give life meaning through suffering become an inescapable given. By and through new scientific advances in the field of genetics and successes with in vitro fertilization, the real potential exists to prevent, in large measure, much human suffering before it manifests itself in or through life (Smith, 1981).

\section{Altering Human Evolution}

Today, man is in a position not only to alter the social and environmental conditions of the universe, but also to change his very essence. The mythology of the Minotaur and the Centaur, half man and half animal, may well become the reality of the twenty-first century. Indeed, not only is modern medicine attempting to create man-animal combinations, but also man-machine combinations, or cyborgs. Plastic arteries, artificial limbs, and pacemakers highlight the efforts of modern science to replace diseased or worn out parts of the human body (Smith, 1983).

The central question which arises in relation to the current scientific advances is whether genetic engineering should be promoted and encouraged as a basic recognition of the freedom of scientific inquiry and right of privacy. Significant potential dangers are present in conjunction with the almost limitless opportunity for scientific advancement within the technology of recombinant DNA, commonly referred to as genetic 
engineering. The fear that the proverbial "mad scientist," working independently or with an enemy foreign power, could isolate and then proceed to duplicate a cancer organism and possibly place it in public water supplies is not easily dismissed. Acts of thoughtless negligence in a laboratory could result in the "escape" of a deadly microbe. Regarded as the most significant step in the field of genetics since 1953, research in recombinant DNA technology will facilitate identification of every one of the 100,000 genes in the human cell. Armed with this information, efforts could be directed toward replacing defective genes with healthy ones. Thus, the hope is that by making such replacements, genetic diseases such as hemophilia and sickle-cell anemia could be conquered. Indeed, the plenitude of new products of nature that could substantially improve the human condition is staggering to the imagination.

In 1993, as the fortieth anniversary of the discovery of DNA was observed, the Human Genome Project continued its work in mapping and sequencing the human genome and also continued to raise alarms over the potential for abuse of such information. For some, the eugenics movement, to this day, casts a shadow over the whole Project (Smith, 1994-95). Now, with the confirmation that a rough draft of the human gene map will be ready in three years, with the definitive map being completed by 2003 , concerns mount over the unnecessary risk of abuse engendered by the mapping of the human genome and emergent rDNA technology (Gillis, 1998).

This biotechnological advance does not extend to social engineering and the development of a "superior" human - a process of which would necessitate germ-line modification. Rather, it holds the promise to revolutionize biology and medicine by allowing researchers to unscramble how the body works at its most fundamental level. More rationally focused concerns may well be raised over the unregulated dissemination of genetic information about an individual, revealing - as such - his genotype risk factors and, in turn, thereby lead to genetic discrimination and invasions of privacy by both employer and health insurance companies. National and transnational legislative drafting efforts are being undertaken presently as safeguards for maintaining genetic privacy and limiting genetic discrimination (Smith, 1998).

Genetic engineering, viewed as an instrument to revolutionize, limits the effect of natural selection and replaces it with programmed decision making. Programmed decision making facilitates, rather than impedes, rational thinking. Is it shameful to acknowledge that man has the capability to be in control of himself? A lack of control over the years has spawned a type of "evolutionary wisdom" which, in turn, resulted in the bubonic plague, smallpox, yellow fever, typhoid, diabetes and cancer. Today, the quest for maximum efficient utilization of biological and medical knowledge represents one of the tenets of the so-called “evolutionary wisdom” (Fletcher, 1978). 
A number of Post-Darwinians in the scientific community assert that there is no wisdom in evolution, only chance occurrence. Few, if any, would be willing to accept unconditionally all that nature bestows, particularly disease. Consequently, science finds itself in the position of trying to both influence and, in many cases, control the process of evolution. Some would go so far as to suggest that dangerous knowledge is never half as dangerous as dangerous ignorance (Toulmin, 1981).

The sanctity of creation and the fundamental right of privacy in procreation, which is an acknowledged basic or fundamental freedom, may be altered by compelling state interests. Is there a more compelling state interest than the desire to stop a "chromosomal lottery" which saddles the economy each year with four million Americans born with diabetes or fifty thousand born with discernible genetic diseases? State interests in minimizing human suffering and maximizing the social good should be validated properly (Glass, 1966).

Opponents of unrestricted genetic research specifically attack its proponents as being both scientifically and socially irresponsible, and the ultimate promoters of a serious environmental disaster. They suggest that nature has developed strong barriers against genetic interchanges between species, and that extreme caution ought to be used during experimentation in this area. Others argue that mankind's genetic inheritance is its greatest and most indispensable treasure which must be protected and guaranteed at any cost. These opponents submit that the evolutionary wisdom of the ages must not be threatened irreversibly or abridged in order to satisfy the ambition and professional curiosity of some members of the scientific community (Howard \& Rifkin, 1977).

Autonomy, self-determination, and a basic sense of freedom must be tempered by logic, objectivity, and a disinterested search for knowledge; a search which may result in the minimizing of human suffering and maximizing of social good. But what is the social good? It is suggested that the social good, within this context, can be equated with an economic policy that lessens the financial burden on citizens which would otherwise support and maintains genetically defective citizens. The wisest policy is, by consensus, that which promotes a good social, economic or otherwise for the greatest number. Thus, human need and well-being shape the degree of positive good resulting from one policy as opposed to another. Alternatively, a determination could be made in order to structure what is right or wrong, good or evil, according to whether the consequences of an act or public policy add to, or detract from, the aggregate human wellbeing (Smith, 1993). 


\section{VALUES IN CONFLICT}

Some would seek to abandon science and reason in favor of mysticism, hermeneutics and transcendental rapture. Sadly, they fail to comprehend that ignorance, not knowledge assures misery; and that the employment of science for inhumane reasons, not science in and of itself, threatens global survival. Reduced to its most fundamental level, then, what is seen is that the pivotal questions confronting the science of human experimentation are two in number: who will control its products, and what purposes will be employed to achieve this end (Fletcher, 1979).

The improvement of human well-being has been, for the most part, the single motivating force in the quest to ensure that all citizens, especially young children, will be safe from all forms of disease; not only genetic and congenital disorders, but uterine infections and a formidable host of other birth defects (Fletcher, 1979). Since the 1930s, for example, human fetal tissue has been an invaluable research tool for molecular biologists as a source of human cell lines. In turn, these cell lines have been widely used in advanced research on viruses, and in the preparation of vaccines (notably, the polio vaccine) against them. More recently, successful research has been conducted on fetal tissue transplants in living subjects for therapeutic purposes, and for developing treatments for Parkinson's disease, diabetes and radiation-induced anemia. What makes fetal tissue so particularly useful for transplantation is the fact that it not only grows rapidly and is very adaptable, but induces a limited immune response from the host (Greely et al., 1989).

\section{SEX SELECTION BEFORE BIRTH}

The September 9, 1998, issue of The Journal of Human Reproduction carries a fascinating report of a three year study conducted by colleagues at The Genetics and IVF Institute in Virginia, analyzing - as such - the collaborative effort at the Institute to offer clients sex-selected children using a new technology called MicroSort. Developed and patented by the United States Department of Agriculture originally as a system-sorting machine designed for animal breeders, this Virginia fertility clinic has adapted the technology to allow couples to choose the sex of their babies in advance of birth. While the technique does not guarantee that a child will be the sex parents may "order," it does appear the most efficient means yet of tilting the odds in favor of a preferred sex (Fugger et al., 1998).

Ethicists have special concerns about this and other genetic enhancement technologies. Already, couples using donor sperm can scan catalogues which describe various traits of men who have offered anonymously their semen, from hair color to math skills to musical talents. The expressed concern is that parents participating in these pro- 
cedures may well have such unrealistic expectations about their children that they will express their disappointment in subtle ways that would harm the developing child after birth (Weiss, 1998a).

In certain cases, sex selection can be justified - for example, when a family carries a gene for a fatal disease that only affects one sex and parents want to have a child of the opposite sex. As well, it is difficult for some to argue against sex selection for a family that has three sons and want desperately to have a girl rather than a fourth son - all in the name of "family balancing" (Weiss, 1998a).

Yet, sex selection may also be used to reinforce social or cultural biases. In China, India, and Taiwan where boys are generally valued more highly than girls, studies have conclusively shown that the introduction of even low-tech sex selection techniques (such as ultrasound imaging to detect female fetuses, which can then be aborted) has led to increasingly skewed birth rates - with many more boys born than girls (Mufson, C., 1993).

Professor Arthur Caplan of the University of Pennsylvania has cautioned that even when there is medical justification for sex selection for example, the presence of a sex-linked inherited syndrome in the family - complex ethical issues can arise. Thus, for example, should a woman have only boys merely because she carries a gene that would increase modestly a daughter's risk of breast cancer (Weiss, 1998a)?

Safety is an additional concern when utilizing this fertility technology. While the selection procedure is effective approximately sixtyfive percent of the time, there is no documentation regarding whether this method causes subtle changes in human sperm (Weiss, 1998a).

\section{IN UTERO EXPERIMENTATION}

In the latter part of 1998, a "pre-proposal" was made to the National Institutes of Health Recombinant DNA Advisory Committee (RAC) for human in utero experiments. The proposal, still under development, is to cure fetuses afflicted with genetic diseases by giving them new genes before they are born - thus preventing prenatal death or life long disability. Until now, the federal government has allowed experimental genetic therapies to be conducted only on adults, or on children in a few instances (Weiss, 1998b).

The scientists propose treating fetuses that have inherited a serious and often fatal immune system disorder called ADA deficiency and those with a blood disorder called alpha thalassemia, which almost always kills fetuses long before they reach term. Among the risks of the procedure is the chance that some of the new genes might get incorporated into the wrong cells, where they may disrupt normal organ development or perhaps cause cancer (Weiss, 1998b). 
Among the reservations raised to the procedure have been lack of confidence that the technique would work, to the questions of whose health is most important to consider when weighing risks - the mother's, the fetus's or that of the child who may be born (Weiss, 1998b).

There is also fear that a distinct possibility exists that this technique will cause not only the intended genetic changes in the fetus's body but also inadvertent changes in the fetus's "germline" cells - its eggs or sperm. Present federal regulations preclude scientists from making human germ line alterations in part because any genetic errors that may be introduced accidentally could be passed down indefinitely for generations (Weiss, 1998b).

At the annual meeting of The American Society for Reproductive Medicine in October, 1998, a novel - yet controversial - human fertility experiment similar to the one that Scottish scientists used to clone Dolly the sheep, was revealed. New York physicians reported that - for the first time, genes had been transferred from an infertile woman's egg into another woman's egg that had its DNA removed. The reconstituted egg is then fertilized with the sperm and implanted into the womb of the infertile woman with the expectation of growing a baby (R. Weiss, 1998c).

If this procedure is perfected, infertile women would be enabled to have genetically related babies that have genes from a father as well as a mother. Thus, while the procedure would not strictly be cloning, it is similar enough to it to be illegal in California where broadly worded anticloning legislation exists (R. Weiss, 1998c).

The broad ethical problem raised here is the desirability of mixing varying amounts of DNA from two women's eggs into a single egg meaning that any resulting child has two genetic mothers - although one woman contributes vastly more than the other and will clearly be the dominant biological mother (R. Weiss, 1998c).

Conducted at New York University after delayed approval from the University's research review board, not only does this procedure provide another option for infertile women - an option, that is, to adoption or creation of a baby through in vitro fertilization, but - at the same time breaks with previous objections to making human genetic alterations that would be passed on to future generations. For, by combining genes from two different women, although but in a small degree, this new procedure advances a human genetic alteration (R. Weiss, 1998c).

\section{TOWARD A STANDARD OF REASONABLENESS}

Man's dehumanization and depersonalization will not be fostered as a consequence of the continued quest for mastery of the genetic code, and the study and use of non-coital reproduction processes. Attendant to the freedom to undertake research into the exciting and fertile frontiers of the 
"New Biology" is a coexistent responsibility to pursue the work in a reasonable and rational manner. Pursuing the "New Biology" in such a manner requires adequate attention to the safety factor in all aspects of the experimentation. The undesirable events of a Brave New World can be tempered only when knowledge is pursued with the purpose of establishing the truth and integrity of the question, issue, or process. The vast potentials for advancing society and ridding it of a verisimilitude of its present ills is an obvious good which must be pursued steadily. Little sustaining harm can result from a reasonable pursuit of truth and knowledge; for, indeed, truth and knowledge are the basic interstices in any balancing test. If actions are undertaken and performed with the goal of minimizing human suffering and maximizing the social good, then the noble integrity of evolution and genetic progress will be preserved.

\section{CONCLUSIONS}

It would appear that eugenics enjoys clearly a dual relationship with genetics - a negative force as to the potentiality for careless, unrestrained application but a positive force as well when the potential for societal advancement is appreciated and, indeed, realized (Smith, 1984). The dynamic vectors of force seen in the application of modern eugenics through efforts of genetic enhancement and "engineering" must be tempered and placed in equilibrium in order to alleviate fears of unbridled scientific slippery slopes (Smith, 1988). Viewed as not only an aid to the tragedy of infertility in family planning, but as a tool for enhancing the health of the future members of society, vital research and experimentation must continue apace in eugenics and genetics. To attempt to sever one from the other assures an impotent, as opposed to a virile, response to both the challenge and the mystery of amazing development of the new reproductive biology (Smith, 1996).

\section{REFERENCES}

Burger, W.E. (1982) Reflections on Law and Experimental Medicine. In George P. Smith (ed.) Ethical, Legal and Social Challenges to a Brave New World. Associated Faculty Press, Gaithersburg, MD, USA, 211.

Fletcher, J.F. (1979) Humanhood: Essays in Biomedical Ethics, Prometheus Books, Buffalo, NY, USA.

Fletcher, J.F. (1978) Ethics and Recombinant DNA Research. Southern California Law Review, 51, 1131-42.

Fugger, G. et al. (1998) Births of Normal Daughters after MicroSort Separation and Intrauterine Insemination, In-Vitro Fertilization or Intracytoplasmic Sperm Injection. Journal of Human Reproduction, 13, 2367.

Furrow, B.R., Johnson, S.H., Jost, T.S., \& Schwartz, R.L. (1991) Bioethics, Health Care Law and Ethics, West Group, Paul, MN, USA. 
Gillis, M. Scientists Speed Up Timetable for Mapping Human Genes, The Washington Post, Sept. 15,1998 , at p. 2.

Glass, J. (1966). The Effect of Changes in the Physical Environment on Genetic Change. In John Roslansky (ed.) Genetics and The Future of Man. Appleton-Century-Croft, New York, NY, USA.

Greely, H. et al. (1989). The Ethical Use of Human Fetal Tissue in Medicine, New England Journal of Medicine, 320, 1093-97.

Heyd, D. (1992) Genethics: Moral Issues in the Creation of People. University of California Press, Berkeley, CA, USA.

Howard, T. \& Rifkin, J. (1977) Who Should Play God? Delacorte Press, New York, NY, USA.

Joffee, M. (1996) Decreased Fertility in Britain Compared With Finland. The Lancet, 347, 1519-24.

Kirby, M. (1986) Human Rights - The Challenge of The New Technology. Australian Law Journal, 60, 170-181.

Kitcher, P. (1996). The Lives to Come: The Genetic Revolution and Human Possibilities. Simon and Schuster, New York, NY, USA, 193-95, 202-209, 326.

Lemonick, T. (1996) What's Wrong With Our Sperm? Time Magazine, Mar. 18, at p. 78.

Mufson, C. China Softens Bill on Eugenics, The Washington Post, Dec. 30, 1993, at A17.

Rifkin, J. (1998) The Biotech Century. Most Tarcher/Putman, New York, NY, USA.

Smith, G.P. (1981) Genetics Ethics and The Law. Associated Faculty Press, Gaithersburg, MD, USA, 1.

Smith, G.P. (1983) Intimations of Immortality: Clones, Cryons and The Law. University of New South Wales Law Review, 6, 119-134.

Smith, G.P. (1984) Eugenics and Family Planning: Exploring The Yin and The Yang. University of Tasmania Law Review, 8, 4-29.

Smith, G.P. (1988) Biotechnology and The Law. Social Responsibility v. Freedom of Scientific Inquiry. Mercer Law Review, 39, 437-451.

Smith, G.P. (1989) The New Biology. Plenum Press, New York, NY, USA, 67-91.

Smith, G.P. (1993) Bioethics and The Law, University Press of America, Lanham, MD, USA, 1-23.

Smith, G.P. (1994-95) Accessing Genomic Information or Safeguarding Genetic Privacy. Journal of Law and Health, 9, 121-131.

Smith, G.P. (1996) Pathways to Immortality in The New Millennium: Human Responsibility in The New Millennium: Human Responsibility, Theological Direction or Legal Mandate. St. Louis University Public Law Review, 15, 447-469.

Smith, G.P. (1998) Harnessing the Human Genome Through Legislative Constraint. European Journal of Health Law, 5, 53-65.

Toulmin, P. (1981) Science and Ethics: Can They Be Reconnected, University of Chicago Magazine, Winter 1981 at p. 2.

Weiss, R. (a) Va. Clinic Develops System for Choosing Sex of Baby, The Washington Post, Sept. 10, 1998, at p. Al.

Weiss, R. (b) Scientists Seek Panel's Advice on In-Womb Genetic Tests, The Washington Post, Sept. 25, 1998, at A2.

Weiss, R. (c) Fertility Experiments Mix Genes of 2 Women, The Washington Post, Oct. 9,1998 at 1. 